\title{
The lack of a child, the loss of a throne: the infertility of the first royal couple of Greece (1833-62)
}

\author{
${ }^{1} \mathrm{E}$ Poulakou-Rebelakou, ${ }^{2} \mathrm{C}$ Tsiamis, ${ }^{3} \mathrm{~N}$ Tompros, ${ }^{4} \mathrm{G}$ Creatsas \\ ${ }^{1}$ Assistant Professor of History of Medicine; ${ }^{2}$ Cytologist, Athens University Medical School; ${ }^{3}$ Lecturer of History, School of History, \\ Archaeology and Cultural Resources, University of Peloponnesus; ${ }^{4}$ Professor of Obstetrics and Gynaecology, Obstetrics-Gynaecology Second \\ Department, Aretaeio Hospital, Athens University Medical School, Athens, Greece
}

\begin{abstract}
The first dynasty in Greece after its independence in 1830 was founded in 1833 with Otto, the son of Ludwig I of Bavaria. In I836 Otto married Amalia, the daughter of the Grand Duke of Oldenburg. The people of Greece anticipated that the marriage would result in an heir to the throne, establishing the new dynasty. The failure of the royal couple to produce an heir was a major reason for their subsequent abdication. For many years both were subjected to repeated examinations by Greek and German physicians, especially Amalia, who was considered to be largely responsible for the infertility. In this paper we discuss possible diagnoses and describe the various treatments suggested for, and applied to, the infertility. We also review the consequent political controversies and the problems created among the royal families of Europe who wanted to replace the Wittelsbach dynasty with another royal line - a situation that led, in 1863, to the succession of the Danish Schleswig-Holstein-Sonderburg-Glücksburg dynasty to the Greek throne.
\end{abstract}

Correspondence to

E Poulakou-Rebelakou,

5 I, Themidos St, Athens I5 I 24, Greece

tel. $+302107462 I 22$

e-mail efpoulrebel@med.uoa.gr

KEYWORDS Amalia of Oldenburg, Greek monarchy, infertility, Otto of Wittelsbach

DECLARATION OF INTERESTS No conflict of interests declared.

\section{INTRODUCTION}

A crown prince acts as a soporific for revolutions, a royal newborn has the power to lull a whole nation.

So wrote one of the biographers of the first king of the new Greek state, expressing the widely held view that the presence of an heir apparent can stabilise a state.' But the eagerly expected son of the royal couple, Otto and Amalia, never came. This lack of an heir led to a rise in popular discontent with the monarchy, culminating in a vigorous antiroyalist struggle that resulted in the abdication of the first modern Greek dynasty in $1862 .^{2}$

In 1833, the Greek people, full of great expectations for a new period of peace after the ten-year War of Independence, had welcomed the 18-year-old Otto as their new king. ${ }^{3}$ Otto was the second son of Ludwig I of Bavaria, a member of the House of Wittelsbach. The spouse chosen for him by his father was Amalia Maria Frederica (Figure I), the daughter of the Grand Duke of Oldenburg, a duchy in northern Germany. ${ }^{4}$ The marriage of the Catholic Otto and Protestant Amalia took place in Munich in 1836, three years after his coronation. ${ }^{5}$ The Greeks' initial impatience to see an heir baptised in the Orthodox faith gradually turned into unrest, resentment and, finally, aversion towards the royal couple. ${ }^{6}$ Despite the efforts of Greek and German physicians, Otto and Amalia remained childless, a state of affairs that preoccupied the press and public opinion and was the subject of satirical caricatures in most European countries.

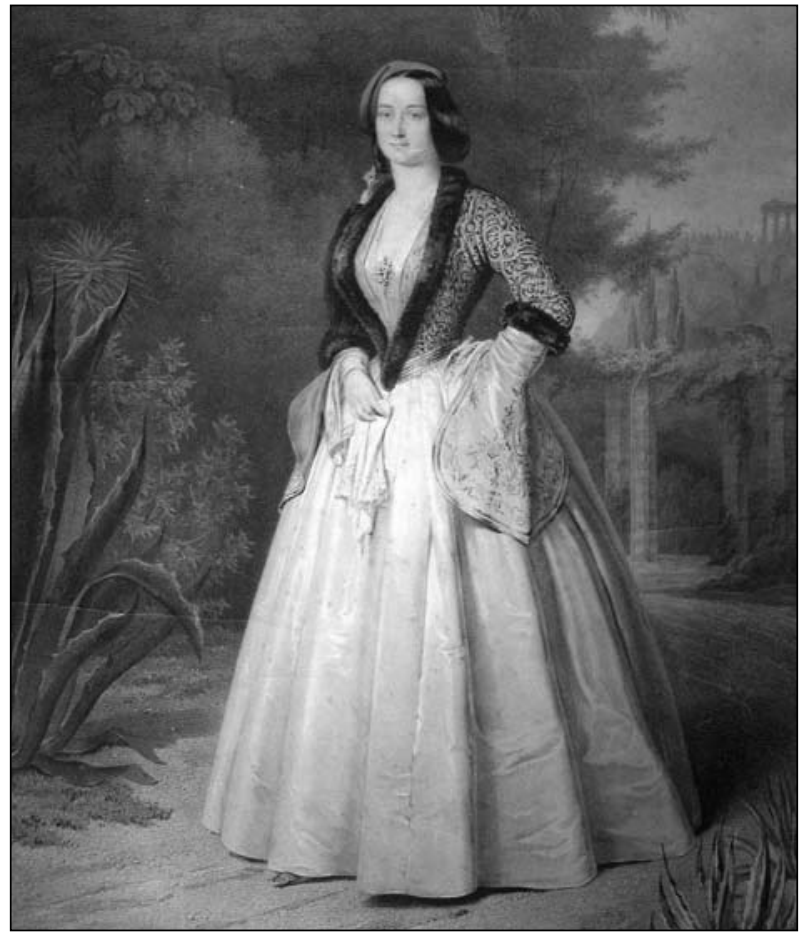

FIGURE I Portrait of Amalia, first Queen of Greece (1836-62). (With kind permission of the Museum of the Historical and Ethnological Society of Greece.)

This paper examines the medical, social and historical aspects of the couple's inability to produce a child, a situation that altered the succession to the Greek throne in favour of George I, the son of the Danish King Christian IX. 
Soon after Amalia's arrival in Athens, rumours started circulating about her being pregnant. However, symptoms of a possible pregnancy were obviously misinterpreted. ${ }^{7}$ The whispers that had begun during the three-year grace period granted to the couple gave way to endless discussions at the Royal Court and in medical circles, before taking on a political dimension and finally becoming a matter of great concern for every citizen of Greece.

Several accounts reflect the active public participation in the problem, as quackery, spells and exorcisms were suggested as possible solutions. The wife of Amalia's priest, Christiane Lüth, records several of these suggestions in her diary: that Amalia should swallow a whole cicada or gunpowder from her husband's pistols mixed with honey, that she should be read poems especially composed for the occasion, that one of her maids should hang an icon of the Nativity outside her door while in disguise. ${ }^{8}$

The efforts to produce a child lasted for at least 15 years, almost up to Amalia's 35th birthday. During this period, whenever political opposition to the throne or another civil crisis was discussed, the subject of the missing Orthodox prince provided dissidents with arguments against the royal couple.

\section{OTTO'S POSSIBLE ROLE IN THE INFERTILITY}

Some stories about Otto in the time before his marriage contradict the rumours of his impotence. As Otto was a minor when he ascended the throne, Greece was governed until 1835 by a regency council of three Bavarians, of whom Count Armansberg was the most influential. Armansberg's wife attempted to marry Otto to one of her three daughters and advised her to care for 'his bodily needs'. ' When Otto's father was informed of her plans, he ordered the young king to avoid being alone with any of the daughters. ${ }^{10}$ There is a suggestion that after Otto's death an old woman claiming to be his daughter placed flowers on his grave every day. ${ }^{7}$ Rumours circulated of Otto's affairs with various ladies of the Court and palace maids, along with the suggestion that he would repay them by arranging for them to marry courtiers or Bavarian soldiers. Only one affair was confirmed, that with Fotini Mavromichali, one of Amalia's ladies-in-waiting and the daughter of a well-known family. ${ }^{7}$ The revelation of this affair led to the expulsion of all Mavromichali's relatives.

At the same time as the Court doctors examined the queen they discreetly examined the king. Dr Wibmer had probably informed Ludwig I that Otto had 'a small anatomical defect'. He unwisely confided this to the English Ambassador in Athens, who, in turn, informed the international press. ${ }^{1}$ "1 Another biographer reports that the Austrian Ambassador Anton von ProkeschOsten was also aware of Otto's physical condition and

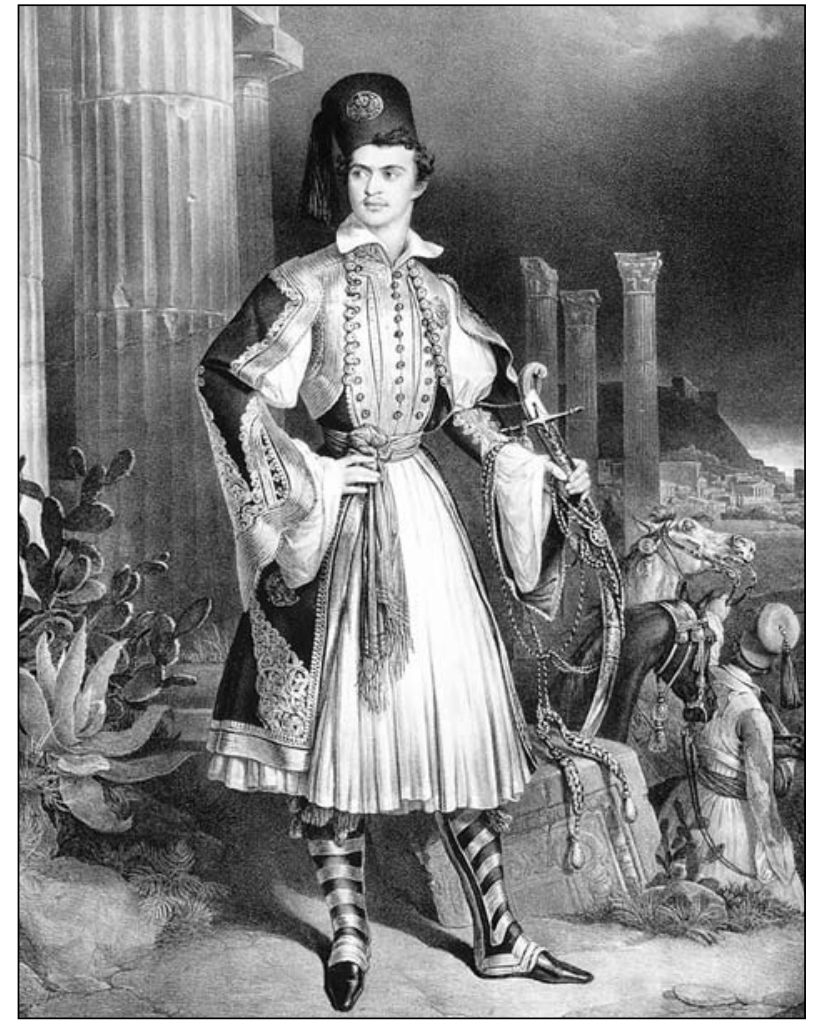

FIGURE 2 Otto of Greece wearing the traditional foustanella (Greek kilt). (With kind permission of the Museum of the City of Athens.)

had sent a report about it to Klemens von Metternich, the Austrian foreign minister. ${ }^{12}$ None of these testimonies were ever officially verified. Indeed, Czar Nicholas I, ignoring the rumours, had intended to marry Otto to one of his own daughters. ${ }^{10} \mathrm{~A}$ propaganda war followed, with Bavaria and her allies denying any physical defect or functional insufficiency in Otto, while their opponents attempted to defend the queen.

Another widely circulated rumour about the Wittelsbach family concerned Ludwig I, Otto's father, who was famous for his extramarital adventures, particularly that with the dancer Lola Montez. It was said that a venereal disease had been transmitted to his sons, rendering all of them infertile. Subsequent events disproved this theory: Otto's three brothers, Maximilian, Leopold and Adalbert, all fathered children. ${ }^{8}$

\section{IMPRESSIONS FROM OTTO'S APPEARANCE}

The differing descriptions of Otto by those who met him personally are often influenced by the observer's personal view of the monarchy. Thus touring European writers visiting Athens regarded him with the respect that his office conveyed, whereas political opponents focused on his bodily defects. Christiane Lüth, a royal courtier, describes him as 'rather handsome, but tired', an opinion shared by the French novelist Edmond About: ' $\mathrm{He}$ is 39 but looks older; he is tall, thin, sickly, exhausted 
by fevers.'13 The Swedish feminist and writer Fredrika Bremer, who visited Greece in 1859, met Otto during a court ball and recorded a rather different impression: 'He has a handsome and manly appearance.'

Otto's participation in therapies for the treatment of impotence was limited to a brief restriction of horseriding and the recommendation of a three-hour rest before sexual intercourse. His doctors expressed concerns about the effect that the traditional foustanella (Greek kilt) he insisted on wearing (Figure 2) might have on his fertility. Lüth added that the queen had also expressed her objections to this attire, as the neck and the arms were exposed and this contributed to his recurrent colds. ${ }^{8}$

\section{IMPRESSIONS FROM AMALIA'S APPEARANCE}

Most reports about Amalia describe her as healthy, robust, athletic and beautiful. ${ }^{8}$ Special mention is made of her vivacity: 'She acted so much, it would often become excessive.'14 The Danish writer Hans Christian Andersen wrote:'She is young and beautiful while her countenance shows calm and prudence.'15 Similar impressions are recorded by the French journalist Antonin Proust. ${ }^{16}$ The influence of political ideas is again evident in the contrasting opinions. For example, the French author Gustave Flaubert described her as ugly ${ }^{17}$ and About, who met Amalia when she was 35, wrote that 'nature has gifted her with a notable appetite'. ${ }^{13}$

There are numerous testimonies to Amalia's riding skills. A 'true Amazon', 8 she visited the whole of Greece on horseback, down to the very last village. However, critics pointed to her frequent visits to Athens city centre on horseback and attributed her sterility to these and other, similar activities. From time to time, especially during various therapeutic attempts to treat the infertility, these activities ceased temporarily. But when all medical efforts proved to be in vain and it became clear that the queen would never become a mother, she returned to her favourite pursuits. ${ }^{10}$

\section{AMALIA'S POSSIBLE ROLE IN THE INFERTILITY}

In the nineteenth century it was common to attribute childlessness to the woman and the royal couple were no exception to this rule. The physicians of the Royal Court and the professors at Athens University, having tried and exhausted all possible therapeutic means at their disposal, asked for help from German colleagues.

Nicholas Louros, Professor of Gynaecology and Obstetrics at the University of Athens between 1932 and 1968, published ten documents consisting of experts' opinions, letters and medical council proceedings between I84I and 1853 on the therapeutic management of Amalia's inability to conceive between the ages of 23 and

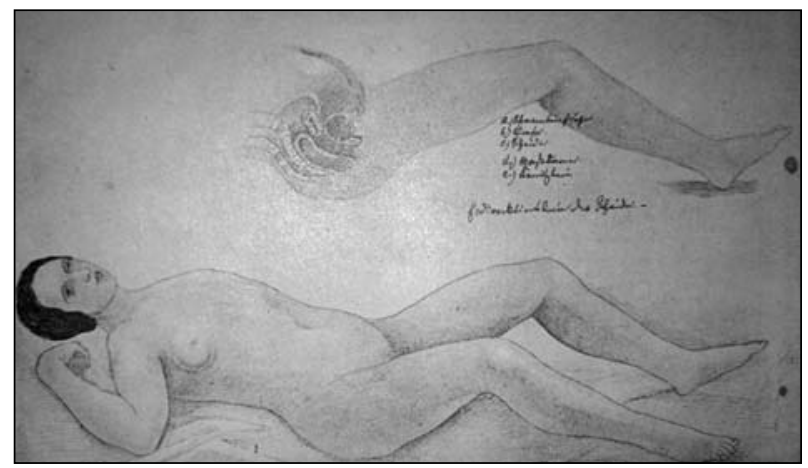

FIGURE 3 A picture accompanying a letter from Dr Bergelied of Germany, depicting the reproductive system of Amalia after a clinical examination (184I). ${ }^{10}$

35. ${ }^{10}$ One clinical examination identified a pelvic anomaly and a womb position 'prohibiting conception' (Figure 3) as well as an 'irritability of the outer genitalia' and 'narrowness of the womb'. The physicians diagnosed an incompatibility between the spouses' genitalia and initially recommended different positions during intercourse but the failure of this simple method obliged them to suggest new therapeutic approaches.

One of the most torturous therapies was the 'sponge therapy' (Dilatationschwämme), strongly supported by a Dr Fischer who tried hard to overcome the numerous objections to this treatment expressed at the Royal Court of Athens. With the support of Otto's mother and brother Maximilian, Fischer tried to persuade Amalia to accept it. He also convinced his Greek colleagues to agree to the therapy, citing the success of this method in three previously childless couples who achieved conception. After the first failure of the technique, Dr Fischer demanded that it be repeated, attributing the lack of success to the brevity of its use and an incorrect application of his technique. ${ }^{10}$

Sponge therapy was aimed at decreasing the "unhealthy sensitivity' of the genitalia and required the introduction, first by a midwife and then by the patient herself, of a sponge into the vagina, followed by bath and rest. The sponge had to remain in situ for 24 hours, until its replacement the following day. Dr Fischer was convinced about the value of the method: 'Waste no more time' and 'replace dilatoriness with intense energy', he wrote, explaining that the introduction of the sponge did not aim to distend an already normally sized vagina but to decrease sensitivity that would not allow normal intercourse. ${ }^{10}$ Supported by his colleague Dr Hirtle, Dr Fischer insisted on continuing the sponge therapy until the very end of the queen's presumed fertile years. The German doctors were keen to comply with the request of Otto's family that they should make full use of scientific methods and ignore the fatalistic views that all should be left in the hands of God. They were also at pains to suppress the view of the Greek doctors that Amalia was in perfect health. ${ }^{7}$ 
Louros comments on the frequency of references by the nineteenth-century gynaecologists to vaginal hypersensitivity, which seemed to be over-diagnosed at the time. He states that he failed to discover any published information about the results of the sponge therapy, even with the aid of Bavarian colleagues. ${ }^{7}$ Although there are some references to the use of sponges, mainly for the dilatation of the vagina to facilitate abortions, the method appears to have been abandoned shortly after its use here. It seems that sponge therapy for vaginal hypersensitivity was both ineffective and uncomfortable.

There is evidence that Queen Amalia at least tried to comply with other therapeutic methods. She repeatedly visited Europe's top spas and bathed at Athens' most popular beach, Faliro, where the people often had the opportunity to see her arriving on horseback to swim for a whole hour. ${ }^{8,18}$

\section{THE RUMOURS ABOUT AMALIA'S VIRGINITY}

Amalia died on 20 May 1875 at the age of 57 . Soon after her death, a rumour began to spread through Europe's royal courts that Dr Viche, who had performed the autopsy at the request of Amalia's brother, found that the former queen had died a virgin. One of her biographers questioned the need for an autopsy, since the clinical cause of her death was pneumonia." A Greek historian, Andrew Skandamis, later attributed the autopsy finding to a political plot, inspired by Amalia's brothers, that aimed to emphasise Otto's impotence. In support of this conspiracy theory, he pointed to the fact that an official report of the autopsy had never been found. ${ }^{19}$ Louros attributed the finding to DrViche's inexperience. ${ }^{10}$

Another source supporting the queen's alleged virginity was a report by von Prokesch-Osten. This was based on an examination by a $\mathrm{Dr}$ Brescau in Munich who did not find any anatomical anomaly and another by a midwife in Athens who found that Amalia was 'almost a virgin'.19 This report shows the political undertones that began to emerge as the Bavarians and Austrians tried to attribute the entire responsibility for the loss of the Greek throne to Amalia and her family.

When the report was found at the Austrian archives by a Greek researcher in 1954 it was sent to the professor of anthropology at Athens University, John Koumaris, for a scientific interpretation of the findings, almost 80 years after the event. His opinion was that there were several possible causes for the queen's sterility: 'either anatomical reasons such as paedomorphic genitalia or neoteny, meaning the retention of juvenile features in adulthood, topographical disorders of the womb or functional reasons as hypersensitivity of the vagina'."

\section{DISCUSSION}

A recent work by Greek medical historians has once more attempted to interpret the couple's sterility by suggesting that Amalia suffered from Mayer-RokitanskyKüster-Hauser syndrome (vaginal agenesis). ${ }^{20}$ In this condition the uterus is absent and there are variable malformations of the vagina, resulting in difficult or painful intercourse. Vladimiros and colleagues reject any idea that Otto might be responsible and focus on the queen's lack of vagina or even womb. However, the reports of the Greek and German obstetricians who examined Amalia leave no doubt that the womb and the vagina existed. ${ }^{10}$

Political pressures undoubtedly sparked rumours and led to official reports about the sterility of the royal couple. Some hypotheses about anatomical or functional disorders cannot be proven without further evidence and remain controversial.

Most twentieth-century researchers considering the historical evidence doubted both Otto's impotence and Amalia's virginity (although Greece's anti-dynastic front spread rumours about the queen's numerous lovers). Louros concluded that Otto either presented some anatomical imperfection or erectile malfunction or that the medical report of the Court doctor, Wibmer, was part of a conspiracy. Yet the fact remains that Greek and German physicians were attempting to cure Amalia's infertility for many years.

Louros also supported the view that the childlessness may have been due to the hypersensitivity of the vaginal entry, which he attributed to Amalia's reactive and strong character and her athletic hobbies. In support of this he suggested that the couple's attempts at sex often ended in failure and led to Otto developing psychological impotency or premature ejaculation. However, Louros accepted that, no matter how adverse, these conditions do not constitute a definite cause of infertility and that the womb's irregular location may explain the inability of conception. ${ }^{10}$

In his biography of King Otto written in 2002, the physician Alexander Zaoussis expressed the opinion that Amalia suffered from dyspareunia due to the increased sensitivity of her external genitalia and the narrowness of her vaginal entry. ${ }^{7}$ He speculated that this condition would have caused Amalia pain during intercourse and, in turn, could have resulted in Otto's inhibition and premature ejaculation. ${ }^{7}$

In 1954 Koumaris diagnosed either a paedomorphism (neoteny) of the genitalia, a topographical disorder of the womb or a malformation of the whole genital system. ${ }^{19}$ 
A review of this evidence suggests that the problem is more complicated than a simple medical diagnosis and even more difficult to solve today because of the frequent contradictions in the historical sources. This is further compounded by observers attributing the responsibility either to the king or the queen, depending on their own political allegiance. The reliability of the sources is questionable, the report of Amalia's autopsy has not been confirmed and historical evidence is often replaced by rumour.

\section{REFERENCES}

I Papantoniou Z. [Otto and the romantic dynasty.] Athens: Hestia; 1934. p. 38-9. In Greek.

2 Petropoulos J. Politics and statecraft in the Kingdom of Greece (I83343).Vol. I-II. Princeton, NJ: Princeton University Press; 1968.

3 Helmberger W. A Bavarian prince becomes King of Greece. In: From Athens to Bamberg. The life of the first royal couple, Otto and Amelia, after 1862. Athens: Museum of the City of Athens VourouEftaxia; 2005. p. 23-33.

4 Rall H. Die Anfänge des confessions-politischen Ringens um den Wittelsbacher Tron in Athens. In: Winkler W, editor. Bayern: Staat und Kirche, Land und Reich. Munich: Staatliche Archive Bayerns; 196I. p. I8I-215.

5 Rüffer M. Otto's first years in Athens. In: From Athens to Bamberg. The life of the first royal couple, Otto and Amelia, after 1862. Athens: Editions of Museum of the City of Athens Vourou-Eftaxia; 2005. p. $35-44$.

6 Daikin D. The unification of Greece 1770-1923. London: Ernest Benn; 1972.

7 Zaoussis A. [Amelia and Otto.] Athens: Oceanida; 2002. In Greek.

8 Lüth C. Fra Fredensborg til Athen: Fragment af en Kvindes Liv. Copenhagen; Gyldendalske; 1926.

9 Seidl W. Bayern in Griechenland. Die Geburt des griechischen Nationalstaats und die Regierung König Ottos. Munich: Prestel; 198I.

If nineteenth-century medical science had succeeded in helping the first royal couple of Greece to conceive, the country might have followed a different historical course. This conclusion is enforced by the fact that the second dynasty, which remained on the throne until 1974, did not face any problems in ensuring their continuity. The second king, George I, certainly did his part in ensuring the succession by fathering no fewer than seven children.
10 Louros NK. [Unpublished documents on the childlessness of Otto and Amelia. Celebratory issue on the 90th birthday of Prof. K. Louros.] Arch Greek Obstet Gynecol 1953; 35-6. In Greek.

II Fotiades D. [Otto. The monarchy.] Athens: Zacharopoulos; 1988. In Greek.

12 Petrakakos D. Parliamentary history of Greece. Vol I. Athens: National Printing House; 1946.

I3 About E. La Grèce contemporaine. 2nd ed. Paris: Hachette; 1855.

14 Bremer F. Greece and the Greeks: the narrative of a winter residence and summer travel in Greece and its islands. London: Hurst \& Blackett; 1863.

15 Andersen HC. En Digters Bazar. Copenhagen:Topsoe-Jensen; 1943.

16 Proust A. Un hiver à Athènes. Paris: Le Tour du monde; 1860.

I7 Flaubert G. Voyages. Vol. I-II. Paris: Les Belles Lettres; 1948.

18 Ross L. Erinnerungen und Mittheilungen aus Griechenland. Berlin: R Gaertner; 1863.

19 Koumaris J. [Origin of the infertility and childlessness of Amalia. Confidential report.] Arch Greek Obstet Gynecol 1954; 3: 105-10. In Greek.

20 Vladimiros LE, Diamantis AG, Androutsos GI. [The cause of sterility of the queen Amelia.] Athens: Zeta; 2008. p. 44-60. In Greek.

\section{UPDATE COURSE ON ELDERLY MEDICINE}

$$
\text { Monday } 16 \text { - Friday } 20 \text { May } 2011
$$

\section{Course Director: Dr Andrew T Elder, FRCP Edin, Consultant Geriatrician}

This biennial course offers a valuable opportunity to discuss clinical issues in elderly care. Places are limited to 60 so early application is advised.

Although the course is designed to appeal to non-UK-based consultants, specialists and senior trainees in elderly medicine, from January $201 \mathrm{I}$ places are also available for doctors resident or working in the UK. Attendance at part of the course is also possible.

Each day will focus on a single clinical topic:

- Monday: Preventing readmission of elderly people

- Tuesday: First do no harm

- Wednesday (half-day): Practical psychiatry for geriatricians

- Thursday: Stroke disease

Friday (half-day): Mobility and function

\section{COURSE FEES:}

Weekly rate: $€ 720$ (inc.VAT) Daily rate:

Mon, Tues, Thurs $£ 200$ (inc.VAT)

Wed, Fri $€ 100$ (inc.VAT)

Late registration fee: $£ 50$ if registering after 4 April 2011

For further details please see: http://events.rcpe.ac.uk or contact: Christina Gray, Education, Training and Standards Department, Royal College of Physicians, 9 Queen Street,

Edinburgh EH2 IJQ, UK

Tel: +44(0) I 3 I 2473607

Email: c.gray@rcpe.ac.uk 